\title{
Correction to: Antimicrobial sensitivity profile and bacterial isolates among suspected pyogenic meningitis patients attending at Hawassa University Hospital: Cross-sectional study
}

Demissie Assegu Fenta ${ }^{1 *}$, Kinfe Lemma ${ }^{2}$, Henok Tadele $^{3}$, Birkneh Tilahun Tadesse ${ }^{3}$ and Birrie Derese ${ }^{4}$

\section{Correction to: BMC Microbiology (2020) 20:125 https://doi.org/10.1186/s12866-020-01808-5}

Following publication of the original article [1], we have been notified that the tagging of one of the author names was done incorrectly. Original and corrected tagging can be seen below. The original article has been corrected.

- Incorrect name tagging: Last Name: Tadesse Tilahun First Name: Birkneh

- Correct author name tagging: Last Name: Tadesse

First Name: Birkneh Tilahun

\section{Author details}

${ }^{1}$ School of Medical Laboratory Science, Hawassa University College of Medicine and Health Sciences, Hawassa, Ethiopia. ${ }^{2}$ Department of Internal Medicine, Hawassa University College of Medicine and Health Sciences, Hawassa, Ethiopia. ${ }^{3}$ Department of Pediatrics, Hawassa University College of Medicine and Health Sciences, Hawassa, Ethiopia. ${ }^{4}$ Department of Neurology, Hawassa University College of Medicine and Health Sciences, Hawassa, Ethiopia.
Published online: 11 June 2020

Reference

1. Assegu Fenta $D$, et al. Antimicrobial sensitivity profile and bacterial isolates among suspected pyogenic meningitis patients attending at Hawassa University Hospital: Cross-sectional study. BMC Microbiol. 2020;20:125. https://doi.org/10.1186/s12866-020-01808-5.

The original article can be found online at https://doi.org/10.1186/s12866020-01808-5.

* Correspondence: demissieasegu@yahoo.com

${ }^{1}$ School of Medical Laboratory Science, Hawassa University College of Medicine and Health Sciences, Hawassa, Ethiopia

Full list of author information is available at the end of the article

(c) The Author(s). 2020 Open Access This article is licensed under a Creative Commons Attribution 4.0 International License, which permits use, sharing, adaptation, distribution and reproduction in any medium or format, as long as you give appropriate credit to the original author(s) and the source, provide a link to the Creative Commons licence, and indicate if changes were made. The images or other third party material in this article are included in the article's Creative Commons licence, unless indicated otherwise in a credit line to the material. If material is not included in the article's Creative Commons licence and your intended use is not permitted by statutory regulation or exceeds the permitted use, you will need to obtain permission directly from the copyright holder. To view a copy of this licence, visit http://creativecommons.org/licenses/by/4.0/ The Creative Commons Public Domain Dedication waiver (http://creativecommons.org/publicdomain/zero/1.0/) applies to the data made available in this article, unless otherwise stated in a credit line to the data. 